\title{
Italy and the Economic Crisis: Political Change and Crisis of Legitimacy
}

\author{
Marco Boschele \\ Esenyurt University; m.boschele@yahoo.co.uk
}

\section{Doi:10.5901/ajis.2015.v4n3s1p147}

\begin{abstract}
Have concepts such as political legitimacy as well as democracy been further undermined by the recent financial crisis of 2008? This is what many social scientists have asked among many other questions which have addressed the effects of the crisis on political institutions and political processes. The change of government in Italy in 2011 and the Italian election of 2013 reflect these assumptions and they reflect the crisis of European politics. In fact, EU countries, notably Southern European countries have had their political and economic agenda dictated by EU bureaucrats and influenced by the Big Three credit rating agencies. There are different indicators which show that the political and democratic institutions of a country are challenged. For instance, the public opinion mistrust about political elites or the effects that globalisation and deregulation have had on societies, in turns, reflect the problem of corruption and illegality, and the erosion of national sovereignty. Within this context, this paper will investigate the crisis of legitimacy and the democratic deficit by analysing the recent events which characterised Italian politics following the economic crisis. Firstly, it will be discussed the relation between the concepts of legitimacy ' $n$ the context of democratic institutions. Secondly, it will be discussed the political situation of Italy since 2011 and the way a technocratic government replaced a democratically elected government as well as a political agenda explicitly dictated by the EU bureaucrats. Moreover, it will be taken into consideration the different factors which led to such a dramatic change.
\end{abstract}

\section{Introduction}

The economic crisis of 2008 was set off primarily by the Anglo American finance sector and by central banks, which tolerated aggressive financial practices (Helleiner 2010). Nevertheless, the crisis also exposed negligent banking practices and long-term government overspending which aggravated the economic performance of countries, particularly in Europe where extraordinary measures have been taken to contain increasing public deficit. Although it seems evident that since at least the 1970s the condition of crisis has characterised the economy of capitalism, it is within these events that the political system of many countries have been put under particular stress. The crisis, in fact, hit particularly European countries, which had an already weak economy, and it caused a crisis of the entire Eurozone.

There are many analyses discussing the impact of the economic crisis on the political structures of modern democracies (Van Rijckeghem and Weder 2008; Gallie (ed.) 2013; Morlino and Piana 2014). Such analyses mainly consider the effect of the crisis in terms of the erosion of sovereignty and democracy, since some states had their economic agenda dictated by the EU commission and by the pressure of economic international institutions. In fact, EU countries, notably Southern European countries have had their political and economic agenda imposed by the EU Commission and influenced by the Big Three credit rating agencies ${ }^{1}$. The change of government in Italy in 2011 and the Italian election of 2013 reflect this outcome and they reflect the crisis of European politics.

Within this context, this paper will investigate the democratic deficit and the crisis of legitimacy in Italy, bearing in mind, however, that the crisis of democracy and legitimacy is a constant of advanced capitalist democracies. Firstly, it will be considered the theories, which analyses the crisis of political legitimacy, of Jürgen Habermas 'Legitimation Crisis' and the 'post-democracy' approach elaborated by Colin Crouch (2004). Moreover, Lauk's argument that in the political structure of the EU there are not the principles, which originated in the European Enlightenment. Secondly, it will be analysed the political situation of Italy since 2011 and the way a technocratic government replaced a democratically elected government as well as a political agenda explicitly dictated by the EU bureaucrats.

These events point out at least two dimensions of the issue of democratic deficit and the crisis of legitimation. One

1 Standard \& Poor's, Moody's, and Fitch Group. 
is about public opinion mistrust of political elites and the second is about the effects that globalisation and deregulation have on societies. It is in times of economic crises that governments have to take drastic measures to tackle and prevent economic recessions and such events expose their efficiency in resolving, within short time, such problems. In the case of Italy, the economic crisis of 2008 uncovered the inefficiency of the state institutions related to both bad administration and corruption within Italy's political elite. Moreover, EU measures, under the SGP (Stability and Growth Pact) ${ }^{2}$ thought to contribute to face the crisis were in fact measures to limit state expenditure, which also prevented investment in innovation. The growing budget deficit put pressure on the government to ensure financial stability through the approval of several cost-cutting policies and since 2011 this model of austerity and fiscal constraint suffocated the fragile Italian economy bringing it in line with negative performances of other countries such as Greece, Portugal, Spain and Ireland (Passarelli and Tuorto 2014:153). The effect of the recession together with the external pressure of the EU institutions forced an unconventional change of governments. In fact, Berlusconi resigned in November 2011 and was replaced by a technocratic government and since 2011 Italy has witnessed three different governments from which at least the first two, influenced by the austerity policies imposed by the EU.

\section{The Crisis of Democracy and Legitimacy in Western Democracies}

In analysing the crisis of legitimacy in advanced democracies, different aspects can be defined. For instance, the negative effects of economic related issues and the effects of globalisation as reflected in the role of supranational institutions and related to this, the inability of democratic institutions to represent the interest of societal groups. In this section, three main approaches, which have characterised the debate about the crisis of legitimacy in Western democracies, will be analysed. The first is that articulated by Jürgen Habermas, "Legitimation Crisis" which points out the government's inability to solve economic crises and the second is that of Colin Crouch (2004), the post-democracy debate, where globalisation, deregulation, loss of collective organisational capacity in society have eroded democracy Merkel (2013). A third understanding of the crisis of democracy and legitimacy can also be seen in the position of Lauk (2014). He maintains that the institution of the European Union and thus EU legislations, were not conceived and established within the principles of the Enlightenment and therefore they lack the kind of consent characteristic of representative democracy and that developed from the Enlightenment movement.

Habermas points out four different types of crisis which are chronologically inter-connected: 'Economic Crisis' related to the economy, 'Rationality Crisis', related to the administrative structure of the state, 'Legitimation Crisis' related to the institutions of democracy and 'Motivational Crisis', related to individuals and their work ethics (Habermas 1975). For Habermas these for dimensions of crisis are identified with the contradictions in capitalist economies in the West. In terms of legitimation crisis, Habermas argues that lack of mass support for democratic institutions occurs because governments are not able to solve economic downfalls, unemployment and social security issues which lead to the legitimation crisis of the state. This may also lead to a crisis of social integration and ultimately to an erosion of work ethic and a 'rejection of capitalist principles of the whole capitalist and democratic order' (Merkel 2013).

The second analysis about the crisis of legitimacy in Western democracies is addressed by the post-democracy debate elaborated by Colin Crouch (2004). The latter argues that the 'democratic moment' has passed for the Western world. Globalisation, deregulation, 'loss of collective organisational capacity' in society have eroded democracy. Although formal democratic institutions continue to exist, they have lost their essence (Crounch 2004:22). Crouch focusses on the new 'imbalance collective organisations of capital and labour'. The less advantaged groups in society do not have a collective identity and the ability to organise collective action. For this reason, private funds for political campaigns, the powerful position of multinational companies, influential lobbies together with the inability of concerted action of the lower classes have created a post-democratic situation. Privatisation and neo-liberalization are in contrast with the principle of democracy in the post democratic age and traditional mass democracy based on party discipline is slowing getting weaker and eventually will dissolve.

A third analysis that highlights the erosion of democracy by supranational institutions is that of Lauk who analyses

\footnotetext{
2 The Maastricht Treaty of 1992 set the rules for all member states to achieve the Economic Monetary Union (EMU), targeting low inflation, low interest rates and contained public debt and spending. The intention was to keep state expenditure under control in order to create a stable condition for the new currency to come. The SGP was than agreed in 1997 and these rules were set to keep the annual budget deficit below $3 \%$ of the GDP and the total public debt $60 \%$ of the GDP. Failing to respect these parameters resulted in the country to take measures to reduce its deficit. If it broke these rules for three consecutive times, the Commission could impose a fine of up to 0.5 of the GDP (CIVITAS).
} 
the political institutions of the EU and maintains that in the political structure of the EU there are not the principles which originated in the European Enlightenment. Which means that the law making process is without legitimation. This is because there is not a European parliament that has the right to initiate and create any law. Moreover, the EU parliament is denied from the function of a democratic parliament where the 'will of the people' has the characteristic of selfdetermination. In the European settings, the right of the legislative branch to initiate is conferred to the executive branch, the EU Commission which is not democratically elected ${ }^{3}$. In these settings, there is not just a 'democratic deficit' but also a totalitarian feature since the Commission is composed of unelected bureaucrats. If the European parliament does not have the right to instruct the EU Commission it follows that in the EU an unelected executive determines how the EU should be governed (Lauk 2014:5-6).

Lauk identifies two factors which are responsible for the question of illegitimacy of EU legislation. The first is that there is a high number of lobbyists (17.000) which have more political weight than the EU voters who are also mostly unware of the decisions taken in Brussels. The second factor is that when an unelected official of the Commission appoint the members of the unelected so-called expert groups to draw a law, those experts are drawn from lobbyist or industry insiders. Moreover, former EU officials hold positions in those industries that they have asked to regulate 4 . According to Lauk, the financial industry was regulated in this way and paradoxically, the same groups of experts appointed with the task of finding solutions to the crisis were the same insiders implicated in the crisis.

These three theories about the crisis of democracy point out three different dimensions of the crisis which are interconnected. In the case of Habermas'legitimation crisis', the economic factor is important since it triggers a series of events which eventually results in the lack of public support for the administrative system and the legitimation crisis of the state. In the case of the post democratic theory, the cause of democratic and legitimacy deficit is the effect of globalisation on national governments and the way administrative systems are delegitimised because they do not represent the interest of social groups but are influenced by powerful multination companies. In this respect, the EU institutions, with its democratic deficit ,due to the way they are functioning, have the effect of circumventing the governments of national states where democratic representation takes place. This was particularly true when actions under the name of austerity measures were taken in order to deal with the effects of the 2008 economic crisis.

\section{The Economic Crisis and Democratic Deficit in Italy}

The 2008 economic crisis had an effect on the political structure of Italy. In 2011, a technocratic government replaced a democratically elected government and particularly measures were taken, by the EU commission, for countries which had a high public debt in order to save the Eurozone. Since 2011 Italy had also fallen into recession and severe economic contraction, which only recently (end of 2015) has started to give timid and positive responses. The economic crisis also has had an effect on Italy's economic performance. In 2013, the GDP fell causing the longest recession in 20 years. Individual and household consumption expenditure decreased from 2012 until early 2015, also with critical labour difficulties to the point that unemployment reached a peak of more than 3 million (13\%) with 40\% amongst the youth (Passarelli ve Tuorto, 2014:153). Italy also faces some challenges also in the sphere of research and innovation. Firstly, there are insufficient reforms and low performance of the higher education system and there is low share of skilled human capital. The higher education system lacks financial and human resources and the effects of the crisis and corruption on the finances of the government are impeding future development.

The technocratic executive led by former EU commissioner Mario Monti took office in November 2011 replacing the Berlusconi government after he had resigned. This change was described as an emergency measure to deal with financial and economic difficulties. The crisis deposed the leader who dominated Italian politics for two decades, Silvio Berlusconi and its Pdl (People of Freedom party). The reason for this downfall was Italy's soaring bond yields which

\footnotetext{
${ }^{3}$ (Art. 17. No. Lisbon Treaty)

${ }^{4}$ The In 1999 the EU established the Financial Service Action Plan (FSAP) with the purpose to create a single market and financial corporations had a great influence on the FSAP. An important player was the Commission High Level Review Group with its members coming from the financial sector. Other expert groups were industry bias. The Report Alliance for Lobbying Transparency and Ethics Regulation denounced concern about the democratic decision making within the Commission for not taking into account all concerned views. According to its own rules the Commission, when drafting new legislation, is supposed to consult as widely as possible to minimise the risks of vested interest affecting the advice. In fact from 167 expert of the Exper Groups, 160 were from the financial industry. The De Larosiere group appointed with the task of proposing a reaction to the crisis was dominated by the financial sector insider implicated in the crisis (Lakus 2014:7).
} 
entered the 7\% danger zone, generally regarded as unsustainable (EU Austerity Drive - BBC 2012). The markets were very uncertain about Italy's public debt, which rose to 1.9 trillion euros (approximately 120\% of GDP) at the end of 2011. It was in fact a technocratic government with people outside the world of politics with the support of the centre-right and centre-left parties PdL and PD (Democratic Party) (Marangoni 2012:140-43). The government in fact took office with the task of managing and seeking to withstand the period of economic and financial crisis and reducing the huge size of public debt. In addition, this was a move to show the Eurozone leaders credible leadership in the country. The first stability budget law included pension reform and a property tax in order to reassure the markets. Nevertheless, the government greatest achievement was that of restoring credibility for the Italian political system. The Monti government also held a spending review that brought $a € 3$ billion cut in spending out of a $€ 300$ billion budget.

Although Monti enjoyed high levels of personal credibility during his short period as prime minister, his anti-crisis measures disappointed many Italians due to their reform and cuts on pensions and increase of property taxes. On 21 December 2012 Mario Monti, after a year as a prime minister, resigned. The resignation of Monti, however, coincided with the end of the electoral mandate and the 2013 general elections produced an extremely complicated puzzle and turnout dropped to an oddly low level for a parliamentary election in Italy (75\%) (Diamanti 2013).

The Democratic Party (PD) and the PdL, the two main parties, lost millions of votes in comparison with their performance at the 2008 elections (Passarelli and Tuorto, 2013). The real winner of the election was the M5S (Five Star Movement), which obtained $25 \%$ of the vote. This new party, formed and led by the comedian and popular blogger Beppe Grillo, also prevented the formation of a centre-left government. Following the consequences of the economic crisis, Italian voters punished the political parties and prevented the opposition to acquire a substantial majority. In fact, almost half of the voters chose to give their votes to an anti-party movement or preferred abstention (D'Alimonte 2013).

In this situation, and with the inability to form a government, the Italian president Giorgio Napolitan $0^{5}$, in order to avoid another election appointed a government of national unity that could continue with the reforms requested by the EU. The Letta government took sit on the 18th of April 2013 and sought to take advantage of the degree of autonomy guaranteed to it by the situation of emergency generated by the economic crisis. The new government also had to manage a majority sustaining a grand coalition which was very diverse and fragmented (Newell and Carbone 2013). However, the Letta government was replaced in February 2014, by a new government. This change was explained by the failure of Letta's attempt or to the lack of effectiveness of the executive he led. This was the political line of the newly elected general secretary of the PD, Matteo Renzi, who demanded and obtained a government change, with the purpose of changing the strategy of the government.

The Renzi government, thus, entered office without being elected. Nevertheless, Renzi obtained a certain degree of democratic legitimacy by wining $40 \%$ of the vote in the European elections. Several elements explain this success. Firstly, as soon as he entered office he spoke out against European austerity and German domination. He called for the revision of the EU treaties and he disputed the idea that there had been an economic recovery. In such circumstances, he was able to propose himself as the man who wanted change immediately, which would improve the living conditions of all Italians. With this approach Renzi also managed to get substantial support from the public opinion and main stream media, who saw in him an element of change and did not seem to be too much concern about the unorthodox way he came to be Prime Minister.

\section{Conclusion}

The effects of the crisis on Italy's economic and political sphere can then be seen in the drastic economic measures imposed by the EU commission under the parameters set by the SGP. All the governments that followed, after the resignation of Silvio Berlusconi, were not formed with the consent of the people given that the coalitions that made possible these governments were made of parties with radical differences. The various changes of government and economic policies which aimed at cutting public expenditure and at radical pension and labour reform, even though necessary, were not the result of internal political discussions within parties but the directives from a supranational level, the EU. Moreover, the results of the general elections in 2013, which did not produce a clear majority, showed the dissatisfaction of the electorate which preferred to give their votes to the M5S as an act of protesting. This act of protest

${ }^{5}$ Giorgio Napolitano interventions have changed the political process or the parties. Napolitano's decision to choose Monti as prime minister also introduced new rules of the game to the practice of government in Italy. This can also be said for the appointment of the Letta government in a situation of political stagnation after the 2013 general elections, and thereafter for the appointment of Renzi. 
aimed at the main parties of the centre left and the centre right accused by the majority of the public opinion of corruption and inability to solve the problems of the country. Indeed, the economic crisis of 2008 exposed the long-term problems of Italy, which would prevents its development in economic terms but also in terms of public administration, in line with the others EU countries. Starting with the problem of corruption which affects the Italian public administration at local and central level and the issue of tax evasion which just in 2014 costed the state 4,1 billion euro.

Within this context, it is possible to see three aspects of the crisis of democratic and political legitimation in Italy. The first one is that proposed by Habermas and it is concerned with the inability of Italian political parties to solve political and economic problems, together with the dissatisfaction of public opinion and lack of trusts in political elites. Much of this discontent is related to the corruption of the political class, mentioned before, and the lack of engagement with the problems of the country. The advent of the crisis, not only weaken the Italian economy but also exposed inefficiency of the Italian political class. If we look at the reforms implemented by the various Italian governments, beginning with the Berlusconi government, which was in power at that moment the crisis began, no particular efforts were made to respond appropriately and contain the economic downfall. The second aspect is related to the effect of supranational institutions and agencies such as the EU, the IMF and the Big Threes. Such institutions can affect the economic policies of a country. Moreover, in the case of the EU, an unelected body of bureaucrats imposed an economic agenda of austerity. This was very much the case of Italy, where the EU Commission demanded change of executive and proposed a list of measures that the government should implement. Lastly, the fact that in modern democracies, the self-regulating market pretends to govern society through technical criteria, questions the concept of legitimacy of political institutions. This is an example of how the economic crisis can be used as a tool of power to implement measures that in normal times would probably be difficult to implement.

\section{References}

Bosco, Anna and Mcdonell, Duncan (2012), Italian Politics: From Berlusconi to Monti Berghahn Books, United States.

CIVITAS Institute for the Study of Civil Society (2012). http://www.civitas.org.uk/eufacts/FSECON/EC10.htm (05- 05- 2015)

Crouch, Colin (2004): Post-Democracy. Cambridge: Polity Press.

D'Alimonte, Roberto (2013). The Italian elections of February 2013: the end of the Second Republic?', Contemporary Italian Politics, . 5, № 2, s. 113-129.

Diamanti, Ilvo, (2013). Un salto nel voto. Roma: Laterza.

Diamanti, Ilvo. (2012, 12 Temuz) . "L'autobus di Grillo nel paese della politica-che-non-c'e." www.Repubblica.it (Erişimi Tarihi: 5 Mayis 2015).

"EU austerity drive country by country" (2012, 21 Mayıs), BBC Europe. http://www.bbc.com/news/10162176 (Erişimi Tarihi: 2 Mayis 2015).

Dlla Porta, Donatella and Andreatta, Massimiliano (2013). "Protesting for justice and democracy: Italian Indignados?" Contemporary Italian Politics, C.5, No 1, s. 23-37.

Gallie, Duncan (ed.) (2013) Economic Crisis, Quality of Work and Social Integration: The European Experience. Oxford, Oxford University.

Habermas, Jürgen (1975): Legitimation Crisis. Boston: Beacon Press.

Helleiner, Eric. 2011. Understanding the 2007-2008 Global Financial Crisis: Lessons for Scholars of International Political Economy. Annual Review of Political Science14: 67-87.

Lauk, C. Tilmann (2014). The Triple Crisis of Western Capitalism: Democracy, Banking, and Currency. Palgrave Macmillan, London.

Marangoni, Francesco (2012). "Technocrats in Government: The Composition and Legislative Initiatives of the Monti Government Eight Months in to its Term of Office", Bulletin of Italian Politics C. 4, No. 1, s. 135-149.

Merkel, Wolfang. (2013). Is there a crisis of democracy? Annual Meeting of the American Political Science Association. http://www.democracybarometer.org/Papers/Merkel_2013_APSA.pdf 03-06-2015.

Morlino, Leonardo and Piana, Daniela (2014). Economic crisis in a stalemated democracy. The Italian case. Working Paper 1/2014 Luiss Academy.

Newell, James L and Carbone, Maurizio (2013), "Italy in the aftermath of the 2013 general elections", Contemporary Italian Politics, C.5, No 1, s. 1-3.

Passarelli, Gianluca and Tuorto, Dario (2014). Not with my vote: turnout and the economic crisis in Italy, Contemporary Italian Politics, C. 6 No 2, s.147-158.

Van Rijckeghem, Caroline, and Weder, Beatrice, (2009). Political Institutions and Debt Crises. Public Choice, Vol. 138, No. 3, pp. 387408. 